\title{
Language legislation in the Belgian Colonial Charter of 1908: A textual- historical analysis
}

For publication in Tove Skutnabb-Kangas and Robert Phillipson (eds), Language Rights, Volume II: Language Policy in Education: Violations or rights for all. London/New York: Routledge. (Series Critical Concepts in Language Studies.).

\section{Keywords:}

linguistic law

language legislation

the Belgian Congo

colonial language policy

linguistic rights

\section{Introduction}

From 1885 through 1908, what is now the Democratic Republic of the Congo was a private possession of the Belgian King Leopold II, known as "the Congo Free State" (Gérard-Libois 1989; Martelli 1962). In 1908, it was transferred to the hands and care of the Belgian State, inaugurating the history of "the Belgian Congo" properly speaking, which ended with Congolese independence on

\section{PLEASE NOTE THAT THIS IS A PREFINAL AUTHOR'S VERSION. IN ORDER TO OBTAIN THE FULL AND FINAL VERSION PLEASE REFER TO \\ https://www.routledge.com/Language-Rights/Skutnabb-Kangas- \\ Phillipson/p/book/9780415740821 \\ or contact the author}

instead read: "The Belgian citizens in the Congo will enjoy the same guarantees as in Belgium concerning the use of languages in the administration and in judicial cases and in particular those ensured to them by the laws of 22 May 1878, 5 May 1889 and 22 February 1908. The decrees organizing the matter will be made no later than five years after the declaration of the present law. All decrees and regulations of a general nature will be written and published in the two languages" (ABCR 24/7/1908: 393). In an oral intervention, he added that the Charter should also include the obligation for all Belgian state personnel in the colonial administration, judiciary, and army to know both French and Dutch.

Renkin's reaction to Henderickx's amendment was partly one of compromise. Asserting that his government was "willing to reconcile all opinions" (ABCR 24/7/1908: 393), he declared himself prepared to expand his own amendment into a new sub-amendment integrating some of the principles advanced by Henderickx, as follows: "In these matters, the Belgian citizens in the Congo will enjoy guarantees similar to those that are ensured to them in Belgium. 
Decrees will be rendered to that effect no later than five years after the promulgation of the present law. "All decrees and regulations of a general nature will be written and published in the French language and in the Flemish language". (ABCR 24/7/1908: 393). But Renkin did not wish to go any further. He retorted that it would be impossible to apply the three specific Belgian linguistic laws mentioned by Henderickx to the Congo, as they were based on the factual partition of Belgium in a Dutch-speaking region (Flanders), a French-speaking one (Wallonia), and a bilingual one (Brussels) and as no such geo-linguistic division obtained in the Congo. ${ }^{1}$ Secondly, he argued that demanding knowledge of the two languages from all officials would seriously jeopardize the recruitment potential of the Belgian government, which was already faced with a shortage of state personnel for the Congo due to the low popularity of such jobs then. Also, it was a Belgian reality at the time that more Flemings were bilingual than Walloons. Hence, Renkin maintained, a requirement of bilingualism would be inequitable towards the latter group, as it would "run the risk of turning them into second-class Belgians" (ABCR 13/8/1908: 691).

In sum, Renkin was very concerned about the eventuality that Flemings would claim exactly the same linguistic rights in the Congo as they enjoyed in the metropole. Instead, their rights had to be "like" the ones they enjoyed in Belgium. In order to arrive at this distinction, he not only omitted the passages on the three Belgian language laws and on compulsory bilingualism for state

\section{PLEASE NOTE THAT THIS IS A PREFINAL AUTHOR'S VERSION. IN ORDER TO OBTAIN THE FULL AND FINAL VERSION PLEASE REFER TO https://www.routledge.com/Language-Rights/Skutnabb-Kangas- Phillipson/p/book/9780415740821 \\ or contact the author}

fear that the Flemings would claim linguistic rights in the Congo fully identical with those they enjoyed in Belgium. Incidentally, no analogous considerations were made in relation to the Dutch text, where the adjective could be considered even more compromising: in all successive versions, the adjective was and remained "gelijk", which is equivalent to the English adjective "same" or "equal", and thus even stronger than the French word "similaire". Clearly, during the drafting and metalinguistic deliberations the French version of the Charter received more attention than the Dutch one.

Sentence II.b mentions that the decrees safeguarding the rights of the Flemings were to appear within five years after the Charter's promulgation. History has proven that Belgian authorities failed to meet this stipulation. Only one language-related decree was ever promulgated, and, for that matter, 44 years overdue, namely on 15 February $1957 .^{2}$ It carried the title "Decree regulating the use of the French and the Dutch language in judicial cases". In general, it allowed Flemish Belgians to be heard and tried in Dutch in courtrooms in the Congo (without, however, obliging all magistrates to be bilingual; in case of need, they were to be assisted by interpreters and translators). Prior to this decree, many analysts argued that

\footnotetext{
${ }^{1}$ During the years of Belgian colonization, some political thinkers in all seriousness suggested to divide the entire territory of the Congo in monolingual French-speaking and Dutch-speaking provinces (Govaerts 2008: 9). ${ }^{2}$ Apart from this decree, in 1939 Governor General Ryckmans in a letter to a province governor recognized the right of every public servant to write his correspondence in his own language (Govaerts 2008: 13-14), a stipulation he would reiterate in 1941 (Govaerts 2007: 15). This recognition remained long unknown, but was amply referred to by Flemish activists in the Congo in the 1950s.
} 
the absence of decrees was unproblematic, as it entailed that the linguistic freedom mentioned in sentence I.a was still "complete" with regard to private language use and that for official contexts the absence of decrees simply meant that the use of French, inherited from times prior to 1908, could be continued (Malengreau 1953; Heyse 1955-1957; see also Govaerts 2007: 28-29). But especially after 1945, Flemish

\section{PLEASE NOTE THAT THIS IS A PREFINAL AUTHOR'S VERSION. IN ORDER TO OBTAIN THE FULL AND FINAL VERSION PLEASE REFER TO https://www.routledge.com/Language-Rights/Skutnabb-Kangas- Phillipson/p/book/9780415740821 or contact the author}

that all paragraphs on language to be inserted in the Charter could "at long last" be voted (ABCR 31/7/1908: 501), he added that one last sub-amendment had been submitted, namely by member of parliament Leo Bruyninckx (1866-1929). Bruyninckx and colleagues proposed to insert the statement "Both texts are official", an amendment which was accepted without much debating and which thus became the final sentence of article 3 (III.b).

The restriction to "of a general nature" in III.a was meant to exclude simple circulars and nominations, as well as regulations and ordinances of purely local purport. In theory, the clause could be interpreted as stating that authors of such "lower" legislative texts could choose to

(ABCR 13/8/1908: 690). The amendment came as a bolt from the blue: the article under discussion on that day revolved around the Belgian Congo's diplomatic relations with other European powers (the eventual articles 27 and 28 in the Charter), involving no reference whatsoever to language. This was clearly an act of despair on behalf of the Flemish activists - a last, ill-timed, convulsion to secure some Flemish claims before the Charter would be submitted to a final vote. The next day, 14 August, Chamber president Gérard Cooreman (1852-1926) in

\section{PLEASE NOTE THAT THIS IS A PREFINAL AUTHOR'S VERSION. IN ORDER TO OBTAIN THE FULL AND FINAL VERSION PLEASE REFER TO https://www.routledge.com/Language-Rights/Skutnabb-Kangas- Phillipson/p/book/9780415740821 or contact the author}

2011a, 2011b). ${ }^{3}$ In this respect, in the mid-1950s a director at the ministry of colonies laconically observed that "the consequences of [the legislator's] inaction is purely of a political order in which the Congolese are not interested" (Heyse 1952-1954: 48). In other words, although never consulted, the Congolese were deemed not to be interested in language matters or linguistic rights, and groups who do not declare themselves interested, so Heyse reasoned, do not need rights.

\footnotetext{
${ }^{3}$ This is not meant to imply that no language policies regarding the indigenous language question were ever developed in the Belgian Congo. Only, they were never enacted in decrees.
} 
Interpreting this lack of consideration and utter disdain for the indigenous languages and language rights against the larger canvas of theories of linguistic human rights (see SkutnabbKangas 2012 and Phillipson and Skutnabb-Kangas 2012), two remarks can be made. First, the historical case study leads to support May $(2000,2008)$ warning that defending and furthering the linguistic rights of one marginalized community, in this case the Flemings in the Congo, may have dire consequences for another community, i.e. the Congolese. This cannot simply be remedied by ensuring that no community is "overlooked" when drafting rights. In Meeuwis (2011a), it is explained how in later decades in the Congo, the Flemish linguistic claims threatened the social-economic emancipation of the Congolese, as the envisaged French-Dutch bilingualization of public service delivery would deny the latter, who had never been given access to Dutch, job opportunities in the colonial administration and local governments. In other words, discussions of linguistic human rights need to remain attentive to the fact that even when group rights are fashioned in parliament, as was done for the Colonial Charter, other groups may experience inherent, undemocratic effects of injustice from such a seemingly "democratic" process.

Secondly, the paradigm of Linguistic Human Rights is premised on categorizations of language, ethnicity, and belonging, and on definitions of and solutions for "problems", all of which are designed and imposed from above (Blommaert 2001; Wee 2005; Makoni 2012). That is, they are formulated from the top down about the individuals concerned, instead of with them, let alone by

PLEASE NOTE THAT THIS IS A PREFINAL AUTHOR'S VERSION. IN ORDER TO OBTAIN THE FULL AND FINAL VERSION PLEASE REFER TO

https://www.routledge.com/Language-Rights/Skutnabb-Kangas-

Phillipson/p/book/9780415740821

or contact the author 


\section{Acknowledgment}

I wish to thank Jean-Luc Vellut, Léon de Saint Moulin, Daniël Vangroenweghe, Honoré Vinck, and Jürgen Jaspers for their invaluable help and feedback.

\section{References}

$\mathrm{ABCR}=$ Annals of the Belgian Chamber of Representatives.

Abrams, I. (2001). The Nobel Peace Prize and the laureats: An illustred biographical history, 1901-2001. Nantucket: Science History Publications.

BAND (1956). De taalregeling in Kongo: Documenten (special issue of Band: Tijdschrift voor Vlaams Kultuurleven, 15/10-11). Leopoldstad: Band.

Blommaert, J. (2001). The Asmara Declaration as a sociolinguistic problem: Reflections on scholarship and linguistic rights. Journal of Sociolinguistics, 5(1), 131-142.

Boelaert, E. (1958a). Afrikaanse talen in het onderwijs in Belgisch-Congo. Koninklijke Academie voor Koloniale Wetenschappen, 4(4), 861-941.

Carton de Wiart, H. (1945). Beernaert et son temps. Brussels: La Renaissance du Livre.

Chumbow, B. S. (2012). Towards a legal framework for language charters in Africa. In C. Brohy, T. Du Plessis, J.-G. Turi, \& J. Woehrling (Eds.), Law, language and the multilingual state (pp. 1-30). Bloemfontein: SUN MeDIA.

Colonna, F. (1997). Educating conformity in French colonial Algeria. In A. L. Stoler, \& F. Cooper (Eds.), Tensions of empire: Colonial cultures in a bourgeois world (pp. 346370.). Berkeley: University of California Press.

de Jonghe, A. (1943). De taalpolitiek van Koning Willem I in de Zuidelijke Nederlanden, 1814-1830: De genesis der taalbesluiten en hun toepassing. Brussels: Steenland.

de Saint-Moulin, L. (1987). Essai d'histoire de la population du Zaïre. Zaïre-Afrique, 27(217), 389-407.

de Saint-Moulin, L. (1990). What is known of the demographic history of Zaïre since 1885? In B. Fetter (Ed.), Demography from scanty evidence: Central Africa in the colonial era (pp. 299-331). Boulder: Lynne Riener.

Gérard-Libois, J. (1989). Du domaine de Léopold II à l'entreprise coloniale. In B. Adam (Ed.), Congo - Zaïre: La colonisation, l'indépendance, le régime Mobutu, et demain? (pp. 11-19.). Brussels: GRIP.

Govaerts, B. (2007). Wilfried Borms in Belgisch-Congo: Een eenmansgevecht voor het Nederlands in de kolonie? Wetenschappelijke Tijdingen, 66(1), 6-33.

Govaerts, B. (2008). De zaak van Rechter Grootaert en de strijd om het Nederlands in Belgisch-Congo: Een symbooldossier uit de jaren vijftig. Wetenschappelijke Tijdingen, 67(1), 7-46.

Halewyck, M. (1910). La Charte Coloniale: Commentaire de la loi du 18 octobre 1908 sur le Gouvernement du Congo Belge. Brussels: Weissenbruch.

Hermans, T., Vos, L., \& Wils, L. (Eds.). (1992). The Flemish Movement: A documentary history (1780-1990). London: Athlone.

Heyse, T. (1952-1954). Congo Belge et Ruanda-Urundi: Notes de droit public et commentaires de la Charte Coloniale, Volume I. Brussels: Van Campenhout.

Heyse, T. (1955-1957). Congo Belge et Ruanda-Urundi: Notes de droit public et commentaires de la Charte Coloniale, Volume II. Brussels: Van Campenhout. 
Hochschild, A. (2011). King Leopold's ghost: A story of greed, terror, and heroism in colonial Africa. London: PanMacmillan.

Lupukisa, W. (1979). Problématique du bilinguisme et du plurilinguisme au Zaïre. African Languages 5(2), 33-44.

Luyckx, D. (1994). Adelfons Henderickx en het activisme in Antwerpen tijdens de Eerste Wereldoorlog. Wetenschappelijke Tijdingen, 53(1), 21-33.

Makoni, S. B. (2012). Language and human rights discourses in Africa: Lessons from the African experience. Journal of Multilingual Discourses, 7(1), 1-20.

Malengreau, G. (1953). De l'emploi des langues en justice au Congo. Journals des Tribunaux d'Outre-Mer, 4(31), 3-6.

Martelli, G. (1962). Leopold to Lumumba: A history of the Belgian Congo, 1877-1960. London: Chapman.

May, S. (2000). Uncommon languages: The challenges and possibilities of minority language rights. Journal of Multilingual and Multicultural Development, 21(5), 366-385.

May, S. (2008). Language and minority rights: Ethnicity, nationalism, and the politics of language. New York: Routledge.

Meeuwis, M. (2004). Joseph Tanghe et le lingala. Annales Aquatoria, 25, 399-431.

Meeuwis, M. (2007). Multilingualism as injustice: African claims on colonial language policies in the Belgian Congo. In P. Cuvelier, T. Du Plessis, M. Meeuwis, \& L. Teck (Eds.), Multilingualism and exclusion (pp. 117-131). Pretoria: Van Schaik.

Meeuwis, M. (2011a). Bilingual inequality: Linguistic rights and disenfranchisement in late Belgian colonization. Journal of Pragmatics, 43(5), 1279-1287.

Meeuwis, M. (2011b). The origins of Belgian colonial language policy in the Congo. Language Matters, 42(2), 190-206.

Phillipson, R., \& Skutnabb-Kangas, T. (2012). Getting languages rights: A response to Makoni. Journal of Multilingual Discourses, 7(1), 29-35.

Piron, P., \& Devos, J. (1954). Codes et lois du Congo Belge. Brussels: Larcier.

Polomé, E. (1968). The choice of official languages in the Democratic Republic of the Congo. In J.A. Fishman, C.A. Ferguson, \& J. Das Gupta (Eds), Language problems of developing nations (pp. 295-312). New York: Wiley \& Sons.

Senelle, R., \& Clément, E. (2009). Léopold II et la Charte coloniale (1885-1908): De l'Etat Indépendant du Congo à la colonie belge. Canet: Mols.

Skutnabb-Kangas, T. (2012). Linguistic human rights. In P. Tiersma \& L. Solan (Eds.), Oxford handbook of language and law (pp. 235-247). Oxford: Oxford University Press.

Stengers, J. (1949). La première tentative de reprise du Congo par la Belgique (1894-1895). Société Royale Belge de Géographie, 73(1-2), 43-122.

Stengers, J. (1963). Belgique et Congo: L'élaboration de la Charte coloniale. Brussels: La Renaissance du Livre.

Stroud, C. (2001). African mother-tongue programmes and the politics of language: Linguistic citizenship versus linguistic human rights. Journal of Multilingual and Multicultural Development, 22(4), 339-355.

Su, J., Turi, J.-G., \& Wang, J. (Eds.). (2006). Law, language and linguistic diversity. Beijing: Law Press.

Tournay-Detillieux, J. (1909). Loi sur le gouvernement du Congo belge: Résumé complet des discussions. Brussels: Bulens.

Turi, J.-G. (2012a). Language law and language rights. International Journal of Law, Language and Discourse, 2(4), 1-18. 
Turi, J.-G. (2012b). Law, language and the multilingual state. In C. Brohy, T. Du Plessis, J.G. Turi, \& J. Woehrling (Eds.), Law, language and the multilingual state (pp. 71-83). Bloemfontein: SUN MeDIA.

Van Bilsen, J. (1950). Au Congo: La question linguistique. La Revue Nouvelle, 11(1), 54-61. Van der Sijs, N. (2004). Taal als mensenwerk: Het ontstaan van het ABN. Den Haag: Sdu. Vanthemsche, G. (2012). Belgium and the Congo, 1885-1980. Cambridge: Cambridge University Press.

Wee, L. (2005). Intra-language discrimination and Linguistic Human Rights: The case of Singlish. Applied Linguistics, 26(1), 48-69.

Willemyns, R. (2013). Dutch: Biography of a language. Oxford: Oxford University Press. Wils, L. (1977). De taalpolitiek van Willem I. Bijdragen en Mededelingen betreffende de Geschiedenis der Nederlanden, 92(1), 81-87.

Wils, L. (1985). De taalpolitiek van Willem I. Wetenschappelijke Tijdingen, 4(44), 193-201. Zajaczkowski, A. (1984). Belgian Congo: Between indirect and direct rule. Hemispheres, 1, 259-270. 